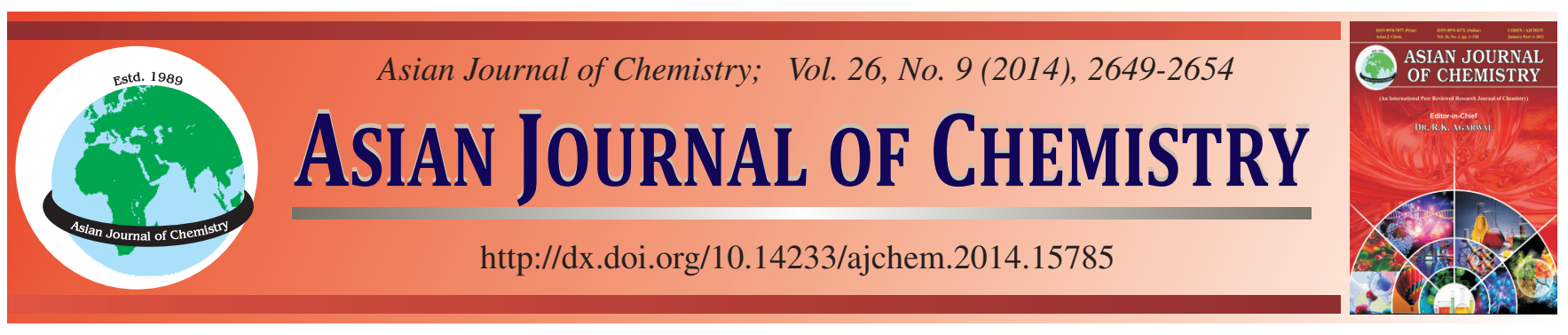

\title{
Adsorptive Removal of Cr(VI) by Acinetobacter junii VITSUKMW3 Immobilized on Coconut Fiber in Batch and Continuous Flow Reactor
}

\author{
Mrudula Pulimi, Jastin Samuel, Chandrasekaran Natarajan and Amitava Mukherjee*
}

Centre for Nanobiotechnology, VIT University, Vellore-632 014, India

*Corresponding author: Tel: +91 416220 2620; E-mail: amitav@vit.ac.in; amit.mookerjea@gmail.com

Received: 16 May 2013;

Accepted: 30 September 2013;

Published online: 28 April 2014;

AJC-15089

\begin{abstract}
The removal of $\mathrm{Cr}(\mathrm{VI})$ by the biomass of Acinetobacter junii immobilized on coconut fiber in batch and continuous systems were investigated. For batch system under optimized conditions ( $\mathrm{pH}$ 2; contact time, $480 \mathrm{~min} ; 30^{\circ} \mathrm{C}$; initial $\mathrm{Cr}(\mathrm{VI})$ concentration of $50 \mathrm{mg} / \mathrm{L}$ ), an adsorption capacity of $17.4 \mathrm{mg} / \mathrm{g}$ was recorded. In continuous packed bed column reactors, a capacity of $39.4 \mathrm{mg} / \mathrm{g}$ was noted with a bed height of $18 \mathrm{~cm}$, a flow rate of $5 \mathrm{~mL} / \mathrm{min}$, an initial $\mathrm{Cr}(\mathrm{VI})$ concentration of $50 \mathrm{mg} / \mathrm{L}$ was employed. The batch sorption data followed the Langmuir isotherm and pseudo first order kinetics. Adsorption studies using $\mathrm{Cr}(\mathrm{VI})$ spiked freshwater, ground water and domestic wastewater in a continuous packed bed column reactors demonstrated $\mathrm{Cr}(\mathrm{VI})$ removals of $29.3,43.6,37.3,25 \%$, respectively.
\end{abstract}

Keywords: Biomass, Coconut fiber, Sorption capacity, $\mathrm{Cr}(\mathrm{VI})$ removal.

\section{INTRODUCTION}

Hexavalent chromium toxicity has become a major concern today because of its deleterious effect on the environment and health. Anthropogenic sources of chromium(VI) are mainly industrial discharges such as tanneries, electroplating, etc. Its high solubility and permeability through biological membranes has lead to mutagenic and carcinogenic effects ${ }^{1}$. Many processes such as precipitation, ion exchange have been in use for the removal of chromium(VI) from the effluents. However, the conventional processes are not cost effective and also generate large quantities of waste. Biosorption of chromium(VI) on low cost materials is gaining considerable popularity as an alternative method for heavy metal ion removal. Several low cost materials such as rice straw, coconut coir, tamarind seeds, wheat bran have been explored for their ability to adsorb chromium(VI) ${ }^{2-4}$. Also, cyanobacteria and bacteria have the capability, to remediate metal ions through biosorption ${ }^{5}$ and studies on microorganisms obtained from contaminated wastewater indicate their capability to remove chromium at a high rate ${ }^{6,7}$. Chromite mine sites in the Sukinda valley, Orissa, India contain a microbial community capable of detoxifying chromium(VI) and tolerating high chromium levels ${ }^{8}$. The chromium(VI) remediation potential by indigenous strains obtained from the Sukinda valley, like Acinetobacter sp., has also been reported ${ }^{5}$. Composite systems such as biomass immobilized on activated carbon and zeolite have also been reported to enhance the biosorption capacity ${ }^{9-11}$.
In the current study, the biosorption capacity of a composite system consisting of coconut fiber and Acinetobacter junii was evaluated. Batch experiments were conducted to investigate the adsorption capacity of chromium(VI) using coconut fiber with the biomass of Acinetobacter junii. The effects of different parameters such as the system $\mathrm{pH}$, adsorbent dosage and contact time were examined. The breakthrough curves for adsorption of chromium(VI) at different concentrations, flow rates and bed depth have also been studied. Also, the efficiency of the system in removing chromium(VI) from spiked environmental water matrices was evaluated.

\section{EXPERIMENTAL}

Bacterial isolate: Chromium(VI) tolerant bacterial isolate Acinetobacter junii VITSUKMW2 (16S rRNA gene sequences JF346549 deposited in GenBank) was grown in molasses media. For the formation of biofilm of $A$. junii., a continuous flow reactor with sterilized coconut fiber was used. The molasses media containing $A$. junii was passed through the column at a flow rate of $2.5 \mathrm{~mL} / \mathrm{min}$ for 4 days. The resultant biofilm immobilized on coconut fiber was used for batch and column studies.

Analysis of chromium: A colourimetric method was employed to analyze the concentration of chromium(VI) remaining in the solution, before and after sorption. Samples were reacted with complexation reagent, 1,5-diphenylcarbazide at low $\mathrm{pH}$ to obtain a purple colour ${ }^{12}$. The measurement was carried out at a wavelength of $540 \mathrm{~nm}$. Total $\mathrm{Cr}$ was measured at a wavelength 
of 359.9 nm using a Flame Atomic Adsorption Spectrophotometer (Analyst400/HGA 900, Perkin Elmer, USA) equipped with a $35 \mathrm{~mA}$ chromium hollow cathode lamp.

\section{Batch biosorption studies}

Optimization of parameters: Batch studies were conducted for biosorption at an initial chromium(VI) concentration of $50 \mathrm{mg} / \mathrm{L}$ and $0.5 \mathrm{~g}$ sorbent in $50 \mathrm{~mL}$ of metal solution at 30 ${ }^{\circ} \mathrm{C}$ for $24 \mathrm{~h}$ at different $\mathrm{pH} 1.0,2.0,4.0,5.0,8.0,10.0$ by adding $0.01 \mathrm{~N} \mathrm{HCl}$. Effect of contact time was studied at an initial chromium(VI) concentration of $50 \mathrm{mg} / \mathrm{L}$ and $0.5 \mathrm{mg}$ sorbent in $50 \mathrm{~mL}$ solution at $30^{\circ} \mathrm{C}$ and optimized $\mathrm{pH}$. Samples were collected for $\mathrm{Cr}(\mathrm{VI})$ at 15, 30, 60, 90, 120, 180, 240, 300, 360, 420, 480, 540, 600, 660, 720 min. Sorption studies at optimized conditions were also carried out with initial $\mathrm{Cr}(\mathrm{VI})$ concentrations in the range of $20-200 \mathrm{mg} / \mathrm{L}$. Sorbent dosage was optimized by using sorbent amounts of 5, 10, 20, 30 and $40 \mathrm{~g} / \mathrm{L}$ in $50 \mathrm{~mL}$ of $50 \mathrm{mg} / \mathrm{L} \mathrm{Cr}(\mathrm{VI})$. The optimization studies were carried out for coconut fiber with and without biomass.

Measurement of batch adsorption capacity, isotherm and kinetics: Metal sorption efficiency of biosorbent was determined by the sorption capacity given as the amount of metal ions adsorbed per unit biosorbent (mg metal ions/g dry biosorbent). Sorption capacity and percentage of biosorption by the biosorbent were obtained by

$$
\begin{gathered}
q=\frac{V\left(C_{o}-C_{e}\right)}{m} \\
\text { Biosorption }(\%)=\frac{\left(C_{o}-C_{e}\right)}{C_{o}} \times 100
\end{gathered}
$$

where $\mathrm{q}$ is the sorption capacity in $\mathrm{mg} / \mathrm{g}, \mathrm{V}$ is the solution volume ( $\mathrm{L}), \mathrm{C}_{\mathrm{o}}$ is the initial $\mathrm{Cr}(\mathrm{VI})$ concentration in $\mathrm{mg} / \mathrm{L}, \mathrm{C}_{\mathrm{e}}$ is the $\mathrm{Cr}(\mathrm{VI})$ concentration at equilibrium and $\mathrm{m}$ is the weight of biosorbent $(\mathrm{g})$.

The adsorption equilibrium data at $30{ }^{\circ} \mathrm{C}$ were modeled using Langmuir, Freundlich and Dubinin-Radushkevich isotherms to study the mode of interaction of $\mathrm{Cr}(\mathrm{VI})$ ions with sorbent when the metal solution phase and sorbent solid phase are in equilibrium.

Pseudo-first order and pseudo-second order models were applied to the sorption data. The model with the highest correlation coefficient value $\left(\mathrm{r}^{2}\right)$, close to unity was considered the best fit.

Continuous flow reactor studies: Continuous sorption experiments were conducted in a glass column $(0.9 \mathrm{~cm}$ internal diameter and $30 \mathrm{~cm}$ height), packed with a known quantity of coconut fiber. Inoculum $(150 \mathrm{~mL})$ of $A$. junii was given to the column every day for 3 days at $2.5 \mathrm{~mL} / \mathrm{min}$. Molasses was pumped through the column at $2.5 \mathrm{~mL} / \mathrm{min}$ for 3 days until $A$. junii isolate biomass was formed on coconut fiber. Chromium(VI) solution $(50 \mathrm{mg} / \mathrm{L})$ was pumped through the column, at desired flow rates using a peristaltic pump. Optimized parameters were used and the $\mathrm{Cr}(\mathrm{VI})$ concentration was estimated by diphenylcarbazide method at different intervals from the sampling point ${ }^{12}$. The packed bed reactor study was carried out at $\mathrm{pH} 2$ and $30{ }^{\circ} \mathrm{C}$. The effect of flow rate on $\mathrm{Cr}(\mathrm{VI})$ adsorption was studied at flow rates of $2.5,5$ and $10 \mathrm{~mL} / \mathrm{min}$ at a bed height of $18 \mathrm{~cm}$ and initial $\mathrm{Cr}(\mathrm{VI})$ concentration of $50 \mathrm{mg} / \mathrm{L}$. Effect of bed height on sorption of $\mathrm{Cr}(\mathrm{VI})$ was evaluated at bed heights of 5, 11 and $18 \mathrm{~cm}$ while flow rate and inlet $\mathrm{Cr}(\mathrm{VI})$ concentration were constant at $5 \mathrm{~mL} / \mathrm{min}$ and $50 \mathrm{mg} / \mathrm{L}$, respectively. Effect of influent $\mathrm{Cr}(\mathrm{VI})$ concentration on breakthrough point and sorption capacity was studied at influent $\mathrm{Cr}(\mathrm{VI})$ concentrations of 25 and $50 \mathrm{mg} / \mathrm{L}$, respectively, at a bed height of $18 \mathrm{~cm}$ and a flow rate of $5 \mathrm{~mL} / \mathrm{min}$.

Viability test: Viability of the bacteria in biomass grown on coconut fiber before and after interaction with $\mathrm{Cr}(\mathrm{VI})$ was determined by colony counts. The biomass was mixed in sterile distilled water and plated on nutrient agar. Also, to examine the release of bacteria during the adsorption process, the effluent was collected and plated on nutrient agar and incubated at $37{ }^{\circ} \mathrm{C}$ for $24 \mathrm{~h}$. The clearly visualized colonies were counted ${ }^{13}$.

Treatment of $\mathrm{Cr}(\mathrm{VI})$-spiked environmental water: Water samples from different locations [Ground water (GW1)-Soloor, Ground water (GW2)-Suthipattu, Lake water (LW)-VIT, Wastewater (WW)-VIT] were collected and adsorption experiments were carried out at optimized $\mathrm{pH} 2,5 \mathrm{~mL} / \mathrm{min}$ flow rate, $18 \mathrm{~cm}$ bed height of sorbent (Coconut fiber with biomass) and $50 \mathrm{mg} / \mathrm{L}$ of influent $\mathrm{Cr}(\mathrm{VI})$ concentration.

Statistical analysis: Each set of the experiment was carried out in triplicates (in batch sorption experiments). One-way Anova with Dunnette's post test was carried out using GraphPad Prism 5.0 software to check statistical significance of the results obtained experimentally.

\section{RESULTS AND DISCUSSION}

\section{Batch sorption studies}

Effect of pH: The $\mathrm{pH}$ of solution play a significant role in the sorption of $\mathrm{Cr}(\mathrm{VI})$ from the aqueous solution. The effect of $\mathrm{pH}$ on the removal of Chromium(VI) is in Fig. 1a. Chromium(VI) removal \% of coconut fiber was maximum (90 and $89 \%$ ) at $\mathrm{pH} 1$ and 2, respectively and decreased gradually till pH $10(13.8 \%)$. Optimized $\mathrm{pH} 2$ for coconut fiber is also similar to the previous studies carried on various sorbents such as HDTMA modified coconut coir pith and coir-based adsorbent, puresorbe $\mathrm{e}^{14,15}$.

In case of the coconut fiber with biomass, $\mathrm{Cr}(\mathrm{VI})$ removal $\%$ at $\mathrm{pH} 1$ and 2 were 98.2 and $93 \%$, which decreased to $33 \%$ at $\mathrm{pH} 10$. The removal $\%$ decreased as the $\mathrm{pH}$ increased from 2 to 10 . Chromium(VI) predominantly exists in the form of monovalent $\mathrm{HCrO}_{4}^{-}$at lower $\mathrm{pH}$ range of 1-4. Thus, at this $\mathrm{pH}$ range the oxyanionic species of $\mathrm{Cr}(\mathrm{VI})$ are likely to get adsorbed on the positively charged biosorbent surface ${ }^{16}$. Therefore removal of $\mathrm{Cr}(\mathrm{VI})$ from aqueous solution was maximum at $\mathrm{pH}$ 1-2 and all the further studies on comparative adsorption of $\mathrm{Cr}(\mathrm{VI})$ by the selected adsorbents were carried out by maintaining the solution at $\mathrm{pH} 2$. Optimum $\mathrm{pH} 2$ obtained for coconut fiber with biomass is well in agreement with the previous studies ${ }^{15}$.

Effect of contact time: The removal \% of Cr (VI) by coconut fiber and coconut fiber with biomass increased steadily up to 94 and $100 \%$ respectively as the contact time increased from $15 \mathrm{~min}$ to 660 and $480 \mathrm{~min}$ respectively (Fig. 1b). The sorption capacity is almost constant beyond 660 and $480 \mathrm{~min}$, which indicates equilibrium conditions due to the lack of active sites left for further sorption. Further experiments were carried 
out keeping the optimum contact time as 660 and $480 \mathrm{~min}$ for coconut fiber and coconut fiber with biomass, respectively.

Effect of sorbent dosage and initial $\mathrm{Cr}(\mathrm{VI})$ concentration: An increase removal \% of $\mathrm{Cr}(\mathrm{VI})$ on coconut fiber from 65.32 to $100 \%$ and coconut fiber with biomass from 73.6 to $100 \%$ with an increase in sorbent concentration from 5 to $40 \mathrm{~g} / \mathrm{L}$ (Fig. 1c). This is due to the availability of sorption sites for the metal ion sorption as the sorbent dosage increased ${ }^{17}$.

The $\mathrm{Cr}(\mathrm{VI})$ removal \% of coconut fiber decreased with an increase in $\mathrm{Cr}(\mathrm{VI})$ concentration up to $200 \mathrm{mg} / \mathrm{L}$ for constant sorbent dosage used (10 g/L) (Fig. $1 \mathrm{~d})$, but the $\mathrm{Cr}$ (VI) removal capacity increased from 1.9 to $13.04 \mathrm{mg} / \mathrm{g}$. Moreover, a high initial $\mathrm{Cr}(\mathrm{VI})$ concentration exerts a driving force to overcome the mass transfer resistance between the solid and the aqueous phase $^{18}$.

Batch sorption studies under optimized conditions: Optimized conditions ( $\mathrm{pH}$ : 2, contact time: $660 \mathrm{~min}$, temperature: $30{ }^{\circ} \mathrm{C}$, initial $\mathrm{Cr}(\mathrm{VI})$ concentration: $200 \mathrm{mg} / \mathrm{L}$, sorbent
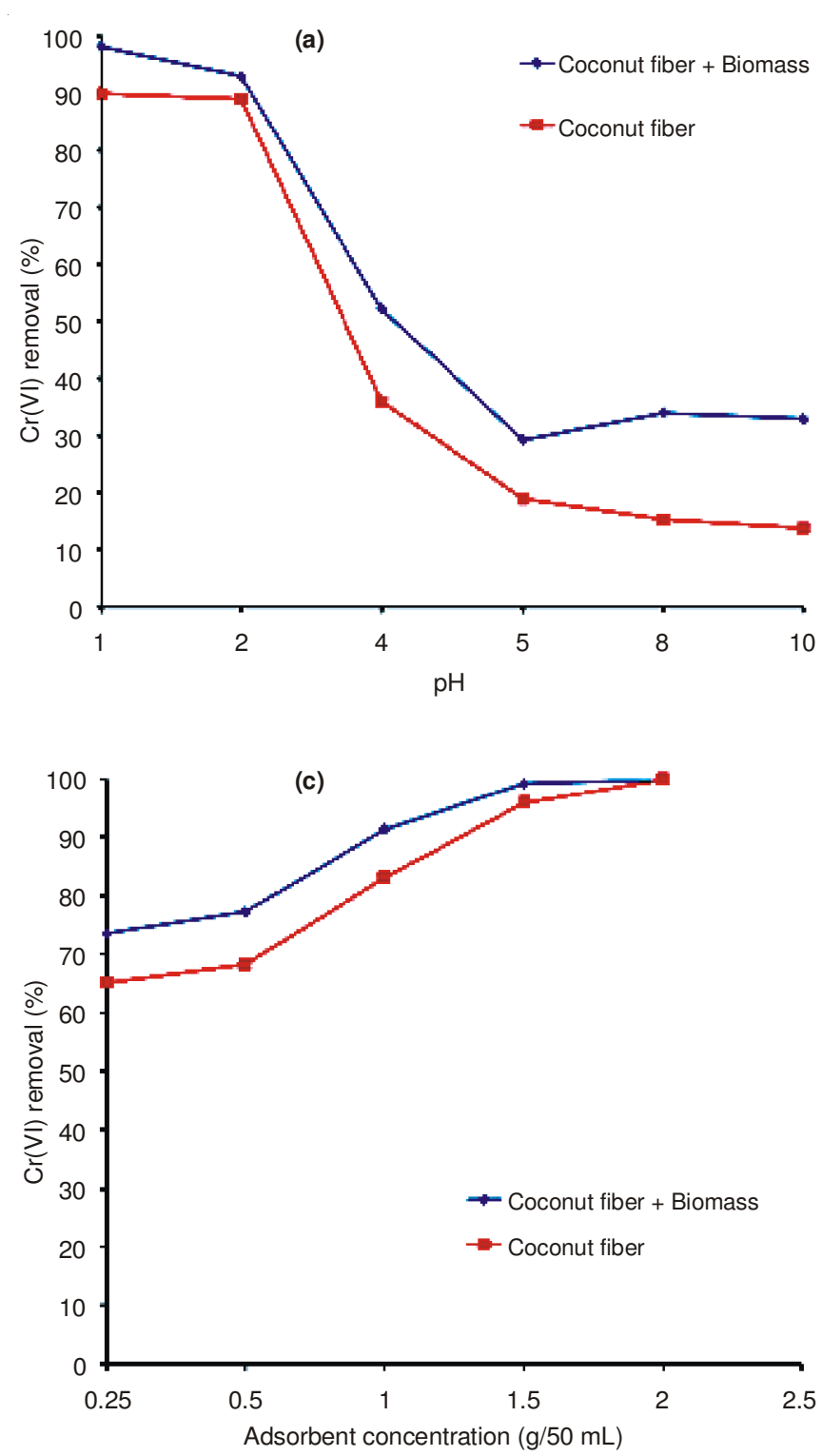

dosage: $10 \mathrm{~g} / \mathrm{L}$ ) were used to carry out the experiments to evaluate the sorption capacity of coconut fiber, which was measured to be of $9.56 \mathrm{mg} / \mathrm{g}$. The $\mathrm{Cr}(\mathrm{VI})$ sorption capacity of coconut fiber with biomass under optimized conditions $(\mathrm{pH}$ : 2.0, contact time: $480 \mathrm{~min}$, temperature: $30^{\circ} \mathrm{C}$, initial $\mathrm{Cr}(\mathrm{VI})$ concentration: $200 \mathrm{mg} / \mathrm{L}$, sorbent dosage: $10 \mathrm{~g} / \mathrm{L}$ ) are 13.04 $\mathrm{mg} / \mathrm{g}$. The increase in the sorption capacity of coconut fiber with biomass compared to coconut fiber alone may be due to increase in the effective binding sites ${ }^{19}$. A statistically significant increase in sorption capacity was observed in coconut fiber with biomass compared to coconut fiber alone by Oneway Anova and Dunnette's post test $(\mathrm{P}<0.05)$. This behavior can be due to the increase of sorption sites for binding due to bacterial biomass present with coconut fiber. The biosorption capacity observed in the current study is high compared to that of the earlier studies carried out using coconut products ${ }^{20-22}$.

Batch adsorption isotherm: Adsorption equilibrium data obtained at $30{ }^{\circ} \mathrm{C}$ was modeled using Langmuir, Freundlich
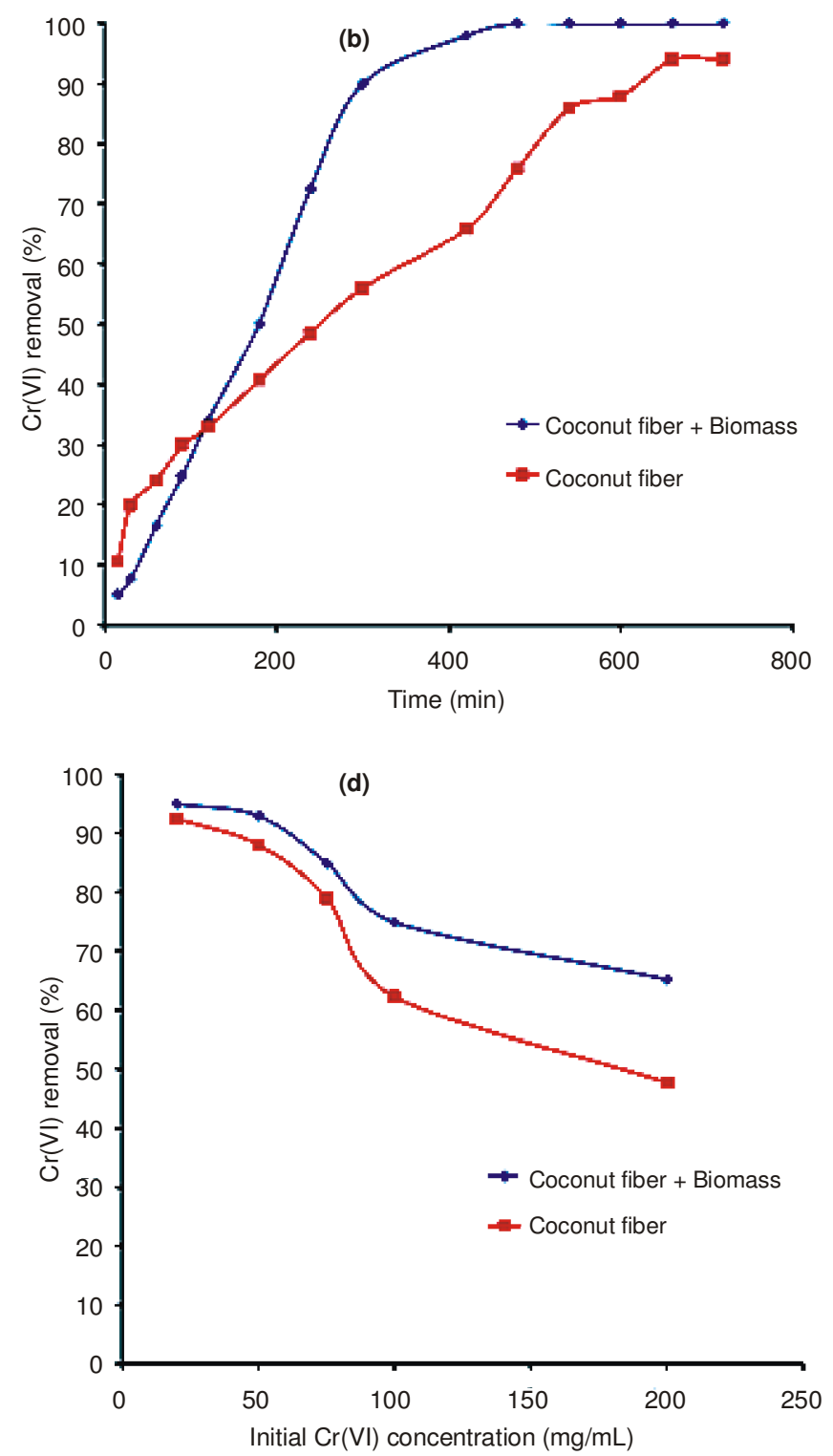

Fig. 1. (a) Effect of pH (b) contact time (c) biosorbent concentration (d) initial Cr(VI) concentration on the sorption capacity of Cr(VI) by coconut fiber and coconut fiber with biomass 
and Dubinin-Radushkevich isotherms. Various isotherm parameters were compared (Table-1). The best fit of the model was obtained in the case of Langmuir model for coconut fiber and coconut fiber with biomass based on highest regression coefficient, $\mathrm{r}^{2}$ (0.97 and 0.93) with $\mathrm{q}_{\mathrm{o}}$ value (10.22 and 14.49 $\mathrm{mg} / \mathrm{g}$, respectively). The theoretically quantified sorption capacity from the Langmuir plot was close to the results obtained by sorption experiments. The Langmuir model is based on the surface homogeneity. This suggests that even at the unavailability of sufficient sorption sites as in the case of coconut fiber and coconut fiber with biomass, a monolayer of sorption devoid of interaction between sorbed molecules is highly probable. Removal of $\mathrm{Cr}(\mathrm{VI})$ from aqueous solution using coconut tree sawdust activated carbon was reported to follow Langmuir isotherm ${ }^{21}$.

\begin{tabular}{|c|c|c|}
\hline \multicolumn{3}{|c|}{$\begin{array}{c}\text { TABLE-1 } \\
\text { COMPARISON OF } \text { q }_{\max } \text { OBTAINED FROM LANGMUIR, } \\
\text { FREUNDLICH AND DUBININ-RADUSHKEVICH ADSORPTION } \\
\text { ISOTHERMS FOR COCONUT FIBER AND COCONUT FIBER } \\
\text { WITH BIOMASS AT OPTIMIZED SORPTION CONDITIONS }\end{array}$} \\
\hline Parameter & Coconut fiber & Coconut Fiber with biomass \\
\hline \multicolumn{3}{|c|}{ Langmuir constants } \\
\hline $\mathrm{q}_{\mathrm{o}}(\mathrm{mg} / \mathrm{g})$ & 10.220 & 14.490 \\
\hline $\mathrm{b}(\mathrm{L} / \mathrm{mg})$ & 0.087 & 0.084 \\
\hline$r^{2}$ & 0.970 & 0.930 \\
\hline \multicolumn{3}{|c|}{ Freundlich constants } \\
\hline $\mathrm{K}_{\mathrm{f}}(\mathrm{mg} / \mathrm{g})$ & 1.896706 & 2.202926 \\
\hline n (L/mg) & 2.777778 & 2.398082 \\
\hline$r^{2}$ & 0.92 & 0.92 \\
\hline \multicolumn{3}{|l|}{ D-R constants } \\
\hline $\mathrm{q}_{\mathrm{D}}(\mathrm{mg} / \mathrm{g})$ & 1.965169 & 2.37684 \\
\hline $\mathrm{B}_{\mathrm{D}}\left(\mathrm{mol}^{2} \mathrm{~K} / \mathrm{J}^{2}\right)$ & 2.31E-08 & $2.96 \mathrm{E}-08$ \\
\hline$r^{2}$ & 0.934 & 0.9 \\
\hline
\end{tabular}

Batch adsorption kinetics: Pseudo first order and pseudo second order kinetics were applied to the kinetics data obtained. The rate constant values $k_{1}$ and $k_{2}$ obtained for pseudo first order and pseudo second order are given in Table-2. The correlation coefficient $r^{2}$ value suggests that the system fit best, pseudo first order for coconut fiber and coconut fiber with biomass than the second order.

\section{Packed bed reactor sorption studies}

Effect of flow rate and bed height: The effect of flow rate on removal of $\mathrm{Cr}(\mathrm{VI})$ by coconut fiber with $\mathrm{A}$. junii biomass was studied. Fig. 2a shows the breakthrough curves for the sorption of $\mathrm{Cr}(\mathrm{VI})$ at different flow rates. It was observed that the breakthrough time decreased from $210 \mathrm{~min}$ at $2.5 \mathrm{~mL} /$ min to $30 \mathrm{~min}$ at $10 \mathrm{~mL} / \mathrm{min}$ flow rate. The decrease in sorption capacity can be explained by the residence time of metal ion in the column. As the flow rate increases, the breakthrough time is less and the curve becomes steeper. This implies that the residence time for the metal ions inside the column has decreased resulting in less sorption due to insufficient sorption time. Hence, lower flow rates are ideal for high sorption capacity of the column. Similar reports have been made in packed bed reactor studies using coconut coir pith for $\mathrm{Cr}(\mathrm{VI})$ adsorption from electroplating industry ${ }^{23}$.

The breakthrough curves for $\mathrm{Cr}(\mathrm{VI})$ sorption at different bed heights were studied. The results (Fig. 2b) show that the breakthrough time and sorption capacity increased from 15 min to $100 \mathrm{~min}$ and $35.7 \mathrm{mg} / \mathrm{g}$ to $39.4 \mathrm{mg} / \mathrm{g}$, respectively. This is mainly due to the higher contact time between metal ions solution and available biosorbent in the reactor and also due to more number of binding sites and ionic groups of biomass available for biosorption of metal ions ${ }^{24,25}$

Effect of initial $\mathrm{Cr}(\mathrm{VI})$ concentration: The effect of influent $\mathrm{Cr}(\mathrm{VI})$ concentration on the breakthrough curves is shown in Fig. 2c. The breakthrough time increased with increasing influent $\mathrm{Cr}(\mathrm{VI})$ concentration. Adsorption capacity increased with increasing influent $\mathrm{Cr}(\mathrm{VI})$ concentration. This can be explained by the fact that at the greater concentration gradient caused a faster transport due to an increased diffusion coefficient or mass transfer coefficient ${ }^{26,27}$. The maximum adsorption capacity of coconut fiber with biomass was 39.4 $\mathrm{mg} / \mathrm{g}$ at $50 \mathrm{mg} / \mathrm{L}$ influent $\mathrm{Cr}(\mathrm{VI})$ concentration, $18 \mathrm{~cm}$ bed height and $5 \mathrm{~mL} / \mathrm{min}$ flow rate. The increase in sorption may be attributed to high influent $\mathrm{Cr}(\mathrm{VI})$ concentration providing higher driving force for the transfer process to overcome the mass transfer resistance ${ }^{28}$. As the influent $\mathrm{Cr}(\mathrm{VI})$ concentration increased from 25 to $50 \mathrm{mg} / \mathrm{L}$, the exhaustion time for coconut fiber with biomass decreased from 315 to $205 \mathrm{~min}$. These results demonstrated that higher initial influent concentrations led to higher driving force for mass transfer. Hence the adsorbent achieved saturation more quickly, which resulted in a decrease of exhaustion time and adsorption zone length ${ }^{28,29}$. From Fig. 2c it is that the breakthrough curves were sharper as influent $\mathrm{Cr}(\mathrm{VI})$ concentration increased, indicating a relatively smaller mass transfer zone and intraparticle diffusion controlled the sorption process ${ }^{28}$. To the best of our knowledge, the maximum adsorption capacity of $39.4 \mathrm{mg} / \mathrm{g}$ at $50 \mathrm{mg} / \mathrm{L}$ influent $\mathrm{Cr}(\mathrm{VI})$ concentration is the highest reported using coconut fiber so far (Table-3) $)^{20-22}$.

Breakthrough curve modeling: For all breakthrough curves, using linear regression analysis, respective values of $\mathrm{k}_{\mathrm{AB}}$ and $\mathrm{N}_{0}$ were calculated (Table-4), along with the correlation coefficients $\left(\mathrm{r}^{2}\right)$. The values of $\mathrm{K}_{\mathrm{AB}}$ decreased with the decrease of flow rate and increase of bed height but increased with increasing influent $\mathrm{Cr}(\mathrm{VI})$ concentration. It shows that the overall system kinetics were dominated by external mass transfer in the initial part of adsorption in the column ${ }^{30-35}$. The Adams-Bohart model provides a simple and comprehensive approach to conduct and evaluate sorption-column test. However, its validity is to the range of conditions used ${ }^{31}$.

TABLE 2

COMPARISON OF PARAMETERS FOR PSEUDO FIRST ORDER AND PSEUDO SECOND ORDER KINETIC MODELS FOR COCONUT FIBER AND COCONUT FIBER WITH BIOMASS AT OPTIMIZED CONDITIONS

\begin{tabular}{cccc|cc}
\hline \multirow{2}{*}{ Biosorbent } & \multicolumn{3}{c|}{ Pseudo first order } & \multicolumn{2}{c}{ Pseudo second order } \\
\cline { 2 - 5 } & $\mathrm{k}_{1}(\mathrm{~min})$ & $\left(\mathrm{q}_{\mathrm{e}}\right)$ & $\mathrm{r}^{2}$ & $\mathrm{k}_{2}(\mathrm{~g} / \mathrm{mg} / \mathrm{min})$ & $\left(\mathrm{q}_{\mathrm{e}}\right)$ \\
\hline Coconut fiber & 0.0009 & 8.9 & 0.99 & 0.00023 & 9.1 \\
Coconut fiber with biomass & 0.0009 & 17.4 & 0.97 & 0.00014 & 17.5 \\
\hline
\end{tabular}



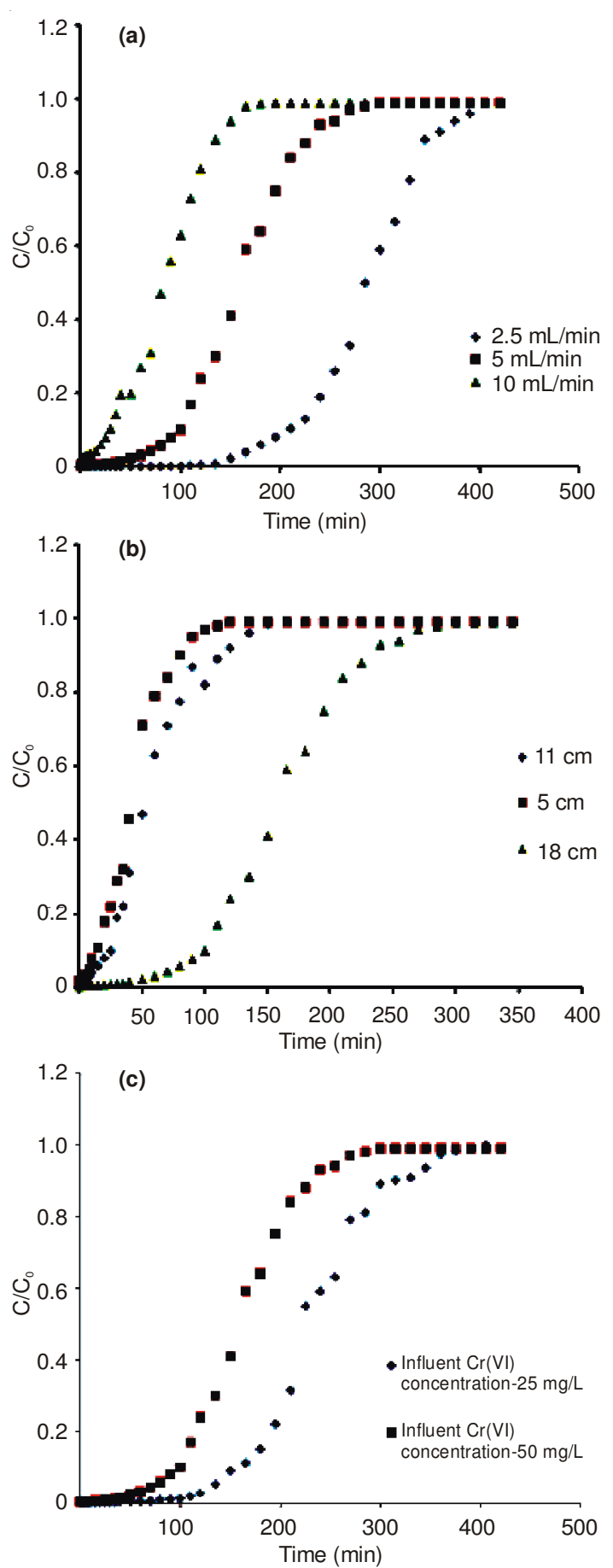

Fig. 2. Effect of (a) flow rate and (b) bed height (c) inlet $\mathrm{Cr}(\mathrm{VI})$ concentration in packed bed reactor using coconut fiber with biomass
The relative constants and coefficients were obtained using linear regression analysis (Table-4). It was shown that the Thomas model ( $\mathrm{r}^{2}$ range from 0.89 to 0.952$)$ provided a better fitting than the Adams-Bohart model. It is that, as the flow rate increased, the value of $\mathrm{K}_{\mathrm{TH}}$ increased while the value of $\mathrm{q}_{0}$ decreased. The value of $\mathrm{K}_{\mathrm{TH}}$ decreased with initial influent $\mathrm{Cr}(\mathrm{VI})$ concentration increasing. It was attributed to the driving force for adsorption in the concentration difference. Thus, the lower flow rate, higher influent concentration and higher bed depth would increase the adsorption of $\mathrm{Cr}(\mathrm{VI})$. The Thomas model was suitable for adsorption process, which indicated that the external and internal diffusions were not the limiting step ${ }^{28,32}$.

Different statistical parameters of the Yoon-Nelson model were calculated (Table-4). The $r^{2}$ values higher than 0.86 indicated the validity of Yoon-Nelson model for the present system. The $\mathrm{K}_{\mathrm{YN}}$ values and the $50 \%$ breakthrough time $\mathrm{s}$ both decreased with increasing bed depth. The value of $s$ decreased as the influent $\mathrm{Cr}(\mathrm{VI})$ concentration increased because the saturation of the column occurred more rapidly ${ }^{33}$. On the other hand, with the increase in the bed height, the values of $\mathrm{K}_{\mathrm{YN}}$ decreased and the values of $\mathrm{s}$ increased. In a comparison of values of $\mathrm{r}^{2}$, both the Thomas and Yoon-Nelson models can be used to predict adsorption performance for adsorption of $\mathrm{Cr}(\mathrm{VI})$ in a packed bed reactor.

Packed bed reactor studies with $\mathrm{Cr}(\mathrm{IV})$-spiked water: Adsorption of $\mathrm{Cr}(\mathrm{VI})$ by coconut fiber with biomass from different environmental water matrices spiked with $50 \mathrm{mg} / \mathrm{L}$ $\mathrm{Cr}(\mathrm{VI})$ were studied (Table-5). In GW1 and GW2, 43.6 and $37.3 \%$ of $\mathrm{Cr}(\mathrm{VI})$ was removed by coconut fiber with biomass with adsorption capacity of 21.3 and $18.18 \mathrm{mg} / \mathrm{g}$ which is less than the adsorption capacity in de-ionized water matrix (39.4 $\mathrm{mg} / \mathrm{g}$ ). In LW and WW, 14.28 and $10.78 \mathrm{mg} / \mathrm{g}$ adsorption capacity of $\mathrm{Cr}(\mathrm{VI})$ at 29.3 and $25 \%$ were removed by coconut fiber with biomass respectively. This suggests the application of coconut fiber with biomass for treating $\mathrm{Cr}(\mathrm{VI})$ in different environmental water matrices.

Viability test: The counts of viable cells in biomass grown on coconut fiber before and after $\mathrm{Cr}(\mathrm{VI})$ interaction were in the range of $3.4 \times 10^{9} \mathrm{cfu} / \mathrm{mL}$ and $3.1 \times 10^{9} \mathrm{cfu} / \mathrm{mL}$ respectively. This explicates that the viability decreased as $0.3 \times 10^{9}$ $\mathrm{cfu} / \mathrm{mL}$ cells were not viable after interaction with $\mathrm{Cr}(\mathrm{VI})$ in continuous flow reactor.

\section{Conclusion}

Coconut fiber with $A$. junii biomass is an effective sorbent for chromium(VI) removal from contaminated waters. The

\begin{tabular}{|c|c|c|c|c|}
\hline & $\begin{array}{l}\text { COMPARATIVE SORPTION CAPACITIES OF CO } \\
\text { CHROMIUM(VI) FROM WATER. THE CURRENT STU }\end{array}$ & $\begin{array}{l}-3 \\
\text { T-BASED B } \\
\text { IOWS HIGH }\end{array}$ & $\begin{array}{l}\text { RBENTS FOR THE REMOV } \\
\text { ADSORPTION CAPACITY }\end{array}$ & $\begin{array}{l}\text { F } \\
\text { EVED }\end{array}$ \\
\hline S. No. & Adsorbent & Adsorbate & Adsorption Capacity (mg/g) & Reference \\
\hline 1 & Coconut shell fibers activated carbon (ATFAC) & $\mathrm{Cr}(\mathrm{III})$ & 12.2 & 20 \\
\hline 2 & Coconut tree sawdust & $\mathrm{Cr}(\mathrm{VI})$ & 3.46 & 21 \\
\hline 3 & Coconut shell charcoal (CSC) & $\mathrm{Cr}(\mathrm{VI})$ & 10.88 & 22 \\
\hline 4 & Coconut shell charcoal (CSC) oxidized with sulfuric acid & $\mathrm{Cr}(\mathrm{VI})$ & 4.05 & 22 \\
\hline 5 & Non-treated CSC coated with chitosan & $\mathrm{Cr}(\mathrm{VI})$ & 3.65 & 22 \\
\hline 6 & Amine-modified polyacrylamide-grafted coconut coir pith & $\mathrm{Cr}(\mathrm{VI})$ & 12.43 & 34 \\
\hline 7 & Coconut coir & $\mathrm{Cr}(\mathrm{VI})$ & $6.3-26.8$ & 2 \\
\hline 8 & Sulphuric acid treated coconut shell activated carbon & $\mathrm{Cr}(\mathrm{VI})$ & 8.42 & 35 \\
\hline 9 & Coconut Fiber with Acenitobacter junii & $\mathrm{Cr}(\mathrm{VI})$ & 39.4 & Current study \\
\hline
\end{tabular}




\begin{tabular}{|c|c|c|c|c|c|c|c|c|c|c|c|}
\hline \multirow{3}{*}{$\begin{array}{l}\text { Height } \\
(\mathrm{cm})\end{array}$} & \multicolumn{11}{|c|}{$\begin{array}{l}\text { TABLE-4 } \\
\text { PARAMETERS OF THOMAS, YOON-NELSON AND ADAMS-BOHART MODEL } \\
\text { UNDER DIFFERENT CONDITIONS USING LINEAR REGRESSION ANALYSIS }\end{array}$} \\
\hline & \multirow{2}{*}{$\begin{array}{l}\text { Flow rate } \\
(\mathrm{mL} / \mathrm{min})\end{array}$} & \multirow{2}{*}{$\begin{array}{c}\mathrm{C}_{0} \\
(\mathrm{mg} / \mathrm{L})\end{array}$} & \multicolumn{3}{|c|}{ Thomas model } & \multicolumn{3}{|c|}{ Yoon-Nelson model } & \multicolumn{3}{|c|}{ Adams-Bohart model } \\
\hline & & & $\mathrm{Q}_{\mathrm{e}}$ & $\mathrm{K}_{\mathrm{th}}$ & $\mathrm{R}^{2}$ & $\mathrm{~K}_{\mathrm{yn}}$ & $\mathrm{T}$ & $\mathrm{R}^{2}$ & $\mathrm{~K}_{\mathrm{ab}}$ & $\mathrm{N}_{0}$ & $\mathrm{R}^{2}$ \\
\hline 5 & 5.0 & 50 & 38.96 & 1.42 & 0.97 & 0.069 & 47.53 & 0.97 & 1.12 & 4.70 & 0.890 \\
\hline 11 & 5.0 & 50 & 27.42 & 1.10 & 0.95 & 0.048 & 70.00 & 0.95 & 0.88 & 2.98 & 0.860 \\
\hline 18 & 5.0 & 50 & 44.23 & 0.57 & 0.97 & 0.028 & 176.92 & 0.97 & 0.39 & 5.34 & 0.890 \\
\hline 18 & 2.5 & 50 & 35.23 & 0.62 & 0.99 & 0.031 & 281.87 & 0.99 & 0.47 & 3.77 & 0.957 \\
\hline 18 & 5.0 & 50 & 44.23 & 0.57 & 0.97 & 0.028 & 176.92 & 0.97 & 0.39 & 5.34 & 0.890 \\
\hline 18 & 10.0 & 50 & 41.89 & 0.86 & 0.99 & 0.043 & 83.72 & 0.99 & 0.38 & 6.87 & 0.840 \\
\hline 18 & 5.0 & 25 & 58.82 & 0.61 & 0.99 & 0.030 & 235.29 & 0.98 & 8.72 & 0.26 & 0.950 \\
\hline
\end{tabular}

\begin{tabular}{ccccccccc}
\multicolumn{2}{c}{$\begin{array}{c}\text { TABLE-5 } \\
\text { CHROMIUM(VI) ADSORPTION BY COCONUT FIBER WITH BIOMASS FROM Cr(VI) } \\
\text { SPIKED DIFFERENT WATER MATRICES IN PACKED BED REACTOR }\end{array}$} \\
\hline Sample & $\begin{array}{c}\text { Flow rate } \\
(\mathrm{mL} / \mathrm{min})\end{array}$ & $\begin{array}{c}\text { Mass of } \\
\text { adsorbent }(\mathrm{g})\end{array}$ & $\begin{array}{c}\text { Bed } \\
\text { height }(\mathrm{cm})\end{array}$ & $\begin{array}{c}\mathrm{C}_{0} \\
(\mathrm{mg} / \mathrm{L})\end{array}$ & $\begin{array}{c}\mathrm{q}_{\mathrm{e}} \\
(\mathrm{mg} / \mathrm{g})\end{array}$ & $\begin{array}{c}\% \mathrm{Cr}(\mathrm{VI}) \\
\text { removal }\end{array}$ & $\mathrm{t}_{\mathrm{b}}$ & $\mathrm{t}_{\mathrm{e}}$ \\
\hline Ground Water 1 & 5 & 1 & 18 & 50 & 21.3 & 43.6 & 45 & 135 \\
Ground Water 2 & 5 & 1 & 18 & 50 & 18.18 & 37.3 & 40 & 110 \\
Waste Water & 5 & 1 & 18 & 50 & 10.78 & 25 & 10 & 70 \\
Lake Water & 5 & 1 & 18 & 50 & 14.28 & 29.3 & 25 & 95 \\
\hline
\end{tabular}

Cr(VI) adsorption by coconut fiber with biomass had an advantage compared to the coconut fiber alone. The advantages of enhanced biosorption potential can be effectively exploited in packed columns for large scale continuous applications for contaminated sites.

\section{ACKNOWLEDGEMENTS}

The authors thank Department of Science and Technology (DST), Government of India for funding this project and also thank the Management of VIT University for their support in research.

\section{REFERENCES}

1. L. Garavaglia, S.B. Cerdeira and D.L. Vullo, J. Hazard. Mater., 175, 104 (2010).

2. M.H. Gonzalez, G.C.L. Araújo, C.B. Pelizaro, E.A. Menezes, S.G. Lemos, G.B. de Sousa and A.R.A. Nogueira, J. Hazard. Mater., 159, 252 (2008).

3. H. Gao, Y. Liu, G. Zeng, W. Xu, T. Li and W. Xia, J. Hazard. Mater., 150, 446 (2008).

4. G.S. Agarwal, H.K. Bhuptawat and S. Chaudhari, Bioresour. Technol., 97, 949 (2006).

5. M.L. Paul, J. Samuel, N. Chandrasekaran and A. Mukherjee, Chem. Eng. J., 187, 104 (2012).

6. P.E. Molokwane, K.C. Meli and E.M. Nkhalambayausi-Chirwa, Water Res., 42, 4538 (2008).

7. K. Sundar, A. Mukherjee, M. Sadiq and N. Chandrasekaran, J. Hazard. Mater., 187, 553 (2011).

8. J. Samuel, M.L. Paul, M. Pulimi, M.J. Nirmala, N. Chandrasekaran and A. Mukherjee, Ind. Eng. Chem. Res., 51, 3740 (2012).

9. C. Quintelas, B. Fonseca, B. Silva, H. Figueiredo and T. Tavares, Bioresour. Technol., 100, 220 (2009).

10. C. Quintelas, Z. Rocha, B. Silva, B. Fonseca, H. Figueiredo and T. Tavares, Chem. Eng. J., 149, 319 (2009).

11. C. Quintelas, Z. Rocha, B. Silva, B. Fonseca, H. Figueiredo and T. Tavares, Chem. Eng. J., 152, 110 (2009).

12. A.D. Eaton, L.S. Clesceri, E.W. Rice, A.E. Greenberg and M.A.H. Franson, Standard Methods for the Examination of Water and Wastewater, 21st edn. American Public Health Association (APHA), Washington (2005).
13. J. Samuel, M. Pulimi, M.L. Paul, A. Maurya, N. Chandrasekaran and A. Mukherjee, Bioresour. Technol., 128, 423 (2013).

14. C. Namasivayam and M.V. Sureshkumar, Bioresour. Technol., 99, 2218 (2008).

15. D. Nityanandi and C.V. Subbhuraam, J. Hazard. Mater., 170, 876 (2009).

16. K. Anjana, A. Kaushik, B. Kiran and R. Nisha, J. Hazard. Mater., 148, 383 (2007).

17. A. Selatnia, M.Z. Bakhti, A. Madani, I. Kertous and Y. Mansouri, Hydro-metallurgy, 75, 11 (2004).

18. S.S. Baral, S.N. Das and P. Rath, Biochem. Eng. J., 31, 216 (2006); .

19. S.K. Singh, A. Bansal, M.A. Jha and A. Dey, Bioresour. Technol., 104, 257 (2012)

20. D. Mohan, K.P. Singh and V.K. Singh, J. Hazard. Mater., 135, 280 (2006).

21. K. Selvi, S. Pattabhi and K. Kadirvelu, Bioresour. Technol., 80, 87 (2001).

22. S. Babel and T.A. Kurniawan, Chemosphere, 54, 951 (2004).

23. P. Suksabye, P. Thiravetyan and W. Nakbanpote, J. Hazard. Mater., 160, 56 (2008).

24. Y.G. Ko, Y.J. Chun, C.H. Kim and U.S. Choi, J. Hazard. Mater., 194, 92 (2011).

25. R. Kumar, D. Bhatia, R. Singh, S. Rani and N.R. Bishnoi, Int. Biodeter. Biodegr., 65, 1133 (2011).

26. M. Tamez Uddin, M. Rukanuzzaman, M. Maksudur Rahman Khan and M. Akhtarul Islam, J. Environ. Manage., 90, 3443 (2009).

27. N. Chen, Z.Y. Zhang, C.P. Feng, M. Li, R.Z. Chen and N. Sugiura, Desalination, 268, 76 (2011).

28. S.S. Baral, N. Das, T.S. Ramulu, S.K. Sahoo, S.N. Das and G.R. Chaudhury, J. Hazard. Mater., 161, 1427 (2009).

29. E. Malkoc, Y. Nuhoglu and M. Dundar, J. Hazard. Mater., 138, 142 (2006).

30. S. Chen, Q. Yue, B. Gao, Q. Li, X. Xu and K. Fu, Bioresour. Technol., 113, 114 (2012).

31. A.A. Ahmad and B.H. Hameed, J. Hazard. Mater., 175, 298 (2010).

32. R.P. Han, Y. Wang, X. Zhao, Y.F. Wang, F.L. Xie, J.M. Cheng and M.S. Tang, Desalination, 245, 284 (2009).

33. M. Calero, F. Hernáinz, G. Blázquez, G. Tenorio and M.A. MartínLara, J. Hazard. Mater., 171, 886 (2009).

34. M.R. Unnithan, V.P. Vinod and T.S. Anirudhan, Ind. Eng. Chem. Res., 43, 2247 (2004).

35. J. Liu, H. Zhang and X. Liu, Adv. Mater. Res., 343, 172 (2011). 